\title{
Pandora's Box: Autoimmune Hypothyroidism Treatment During Pregnancy
}

\author{
Florina-Paula PAULET ${ }^{1}$, Claudia MEHEDINTU²,3, Marina ANTONOVICl ${ }^{3}$, Monica Mihaela CIRSTOIU 2,4
}

\begin{abstract}
There are international protocols for the management of hypothyroidism induced by autoimmune thyroid disease during pregnancy. In this descriptive study, we analyzed the implementation of international protocols regarding these pathologies, in local clinical practice. Analyzing the cases admitted to the Obstetrics and Gynecology department of Bucharest University Emergency Hospital on a period of 55 months, we identified the pregnancies with autoimmune hypothyroidism treated with Levothyroxine (LT4). We determined the prevalence of specific immunological markers for autoimmune hypothyroidism in pregnant women, we analyzed whether they are associated with distinct clinical phenotypes and ultrasound characteristics, and also, we evaluated the treatment of choice. Measurement of thyroglobulin antibodies, thyroid peroxidase antibodies, Thyroid-Stimulating Hormone, free fractions of Triiodothyronine and Thyroxine with substitute treatment instituted early (in the first 2 weeks postnatal) determine the normalization of cognitive development, especially in areas known for iodine deficiency, including Romania.
\end{abstract}

Keywords: hypothyroidism, pregnancy, neonatal prognosis, Levothyroxine.

\section{Rezumat}

Există protocoale internaționale privind gestionarea hipotiroidismului indus de boli tiroidiene autoimune în timpul sarcinii. În acest studiu descriptiv, ne-am propus să analizăm implementarea protocoalelor internaționale corespunzătoare acestei patologii în practica clinică locală. Analizând cazurile internate în Clinica de Obstetrică și Ginecologie a Spitalului Universitar de Urgență București pe parcursul a 55 de luni, am identificat sarcinile asociind diferite forme de hipotiroidism autoimun la care s-a inițiat tratamentul de elecție cu Levotiroxină (LT4). Am determinat prevalența markerilor imunologici specifici pentru hipotiroidism autoimun la femeile gravide, am analizat dacă acestea se asociază cu fenotipuri clinice distincte și cu caracteristici ecografice și, de asemenea, am evaluat tratamentul de elecție. Dozare anticorpilor anti-tireoglobulină și anti-peroxidază tiroidiană, tireostimulinei, fractiilor libere de tiroxina si triiodotironina si instituirea precoce a tratamentului substitutiv (în primele 2 săptămâni postnatal) determină normalizarea dezvoltării cognitive, mai ales în zonele cunoscute pentru deficitul de iod, printre care se numără și România.

Cuvinte cheie: hipotiroidism, sarcină, prognostic neonatal, levotiroxină.

${ }^{1}$ Doctoral School of "Carol Davila" University of Medicine and Pharmacy, Bucharest, Romania

2 Department of Obstetrics and Gynecology, "Carol Davila" University of Medicine and Pharmacy, Bucharest, Romania

3 "Nicolae Malaxa" Clinical Hospital, Bucharest, Romania

${ }^{4}$ Emergency University Hospital, Bucharest, Romania
Corresponding author:

Claudia MEHEDINTU, 8 Eroilor Sanitari Street, Bucharest, Romania

E-mail: claudia.mehedintu@umfcd.ro 


\section{INTRODUCTION}

Hypothyroidism is the most common gestational endocrine disease. Globally, the most common cause for hypothyroidism is iodine deficiency. Other causes include genetic factors responsible for TSH (Thyroid-stimulating Hormone) variations, prior thyroidectomy or ablative radioiodine therapy, whereas secondary (pituitary) and tertiary (hypothalamic) causes are rare (Table 1). Most international guidelines suggest targeted thyroid testing in pregnant women with risk factors for thyroid insufficiency, such as living in iodine-replete areas ${ }^{1}$.
Normally, during pregnancy, the thyroid undergoes reversible morphological and functional changes. The TSH levels decrease slightly at the beginning of gestation due to thyroid stimulation executed by $\mathrm{hCG}(\mathrm{Hu}-$ man Chorionic Gonadotropin, produced by trophoblast cells), the hormone mimicking the effects of TSH at the level of thyroid receptors ${ }^{3}$.

Table 1: Classification of hypothyroidism during pregnancy (adapted) ${ }^{2}$

\begin{tabular}{|c|c|c|}
\hline Subtypes of thyroid disease & Definition & Adverse pregnancy outcomes \\
\hline Overt hypothyroidism & $\begin{array}{l}\text { elevated TSH in combination with } \\
\text { a decreased fT } 4\end{array}$ & $\begin{array}{ll}\text { - } & \text { preeclampsia } \\
\text { - } & \text { gestational hypertension } \\
\text { - } & \text { fetal death } \\
\text { - } & \text { premature delivery } \\
\text { - } & \text { spontaneous abortions } \\
\text { - } & \text { recurrent abortions } \\
\text { - } & \text { cretinism }\end{array}$ \\
\hline Subclinical hypothyroidism & $\begin{array}{l}\text { elevated TSH with a normal range } \\
\text { fT4 }\end{array}$ & $\begin{array}{l}\text { - } \quad \text { preeclampsia } \\
\text { impaired cognitive development of the off- } \\
\text { spring } \\
\text { - } \quad \text { increased risk of perinatal mortality } \\
\end{array}$ \\
\hline Isolated hypothyroxinemia & decreased fT4 with a normal TSH & - premature delivery \\
\hline $\begin{array}{l}\text { Thyroid antibody positivity in } \\
\text { euthyroid women }\end{array}$ & $\begin{array}{l}\text { the presence of one or both an- } \\
\text { ti-thyroid antibodies -TPOAb or } \\
\text { TgAb, irrespective of thyroid func- } \\
\text { tion status }\end{array}$ & $\begin{array}{ll}\text { - } & \text { subfertility } \\
\text { - } & \text { miscarriage } \\
\text { - } & \text { recurrent miscarriage } \\
\text { - } & \text { maternal post-partum thyroiditis } \\
\end{array}$ \\
\hline \multicolumn{3}{|l|}{$\begin{array}{l}\text { TSH - Thyroid-stimulating Hormone, } \\
\text { fT4 - free Thyroxine, } \\
\text { TPOAb - Thyroid Peroxidase Antibodies, } \\
\text { TgAb - Thyroglobulin Antibodies }\end{array}$} \\
\hline
\end{tabular}

In the second part of the pregnancy, the high levels of estrogen produced by the placenta cause an increase in hepatic protein synthesis which include thyroxine binding globulin (TBG). Therefore, the total levels of Thyroxine (T4) and Triiodothyronine (T3) have an increased concentration due to the expansion of the binding fraction. A functionally integer thyroid is capable to compensatory increase its' production, so free T4 (fT4), free T3 (fT3) and TSH remain normal. So, during pregnancy it is recommended to always measure the level of free fractions, not the total concentration of thyroid hormones, which appear falsely increased. The increase in thyroid volume in pregnancy is compensatory due to hormone overproduction, but it is insignificant - about 
10-15\%. In areas with iodine deficiency, however, it can be important and is due to the functional effort of the thyroid to ensure the increased need for hormones ${ }^{4}$.

The need for iodine in pregnancy is greater due to its increased loss via trans-placental passage and accelerated renal clearance. If the adult iodine requirement is $150 \mathrm{mcg} /$ day, during pregnancy and lactation it reaches $200-250 \mathrm{mcg} /$ day. In the first trimester of pregnancy, the baby is completely dependent on the maternal source of thyroid hormones. Subsequently, the fetal thyroid comes into function, but it needs to receive adequate amounts of iodine from the mother's circulation for synthesis of thyroid hormones ${ }^{3}$.

\section{MATERIAL AND METHODS}

In the present retrospective analysis, we sought out to determine the necessity of treatment for pregnant women with autoimmune thyroid pathology. The studied population consisted of 186 pregnancies marked by hypothyroidism out of which 75 cases with acute and subacute thyroiditis, 11 cases with chronic thyroiditis (Hashimoto's lymphocytic thyroiditis), and the rest with autoimmune thyroiditis (Figure 1). Thyroid antibodies - anti-thyroglobulin ( $\mathrm{TgAb}$ ) and anti-thyroid peroxidase (TPOAb) - were considered positive when they were present on two or more occasions, at least 6 weeks apart. The patients were followed at the outpatient clinic of the Department of Obstetrics and Gynecology, University Emergency Hospital, Bucharest, Romania. Informed consent was obtained from all patients. Patients' medical charts were retrospectively evaluated for clinical and laboratory data. Clinical data collection was based on a standardized interview completed by all patients presenting with features of autoimmune diseases.

\section{RESULTS AND DISCUSSION}

In the first stage of statistical evaluation, descriptive tests were applied while monitoring the presence of risk factors and complications in the studied groups. The main parameters analyzed were the fetal weight at birth and Apgar score (to assess the impact on the fetal outcome), as well as the risk of developing preeclampsia, intrauterine growth restriction, diabetes, abruption placentae and premature birth (Figures 2 and 3).

From the cases admitted to the Department of $\mathrm{Ob}-$ stetrics Gynecology of the University Emergency Hospital Bucharest from January 2015 until September 2019, we identified 186 pregnancies associating hypothyroidism. This is reflective of the fact that Romania belongs to an iodinereplete area.

We obtained significant results by comparative analysis of the two groups, respectively, patients with only autoimmune thyroid pathology (mainly autoimmune thyroiditis) undergoing treatment, and patients with unmonitored autoimmune thyroid pathology for the incidence of premature birth, which appears with a significantly increased incidence in the last group. Gestational diabetes also appears with a significantly increased incidence in pregnancies associating thyroid dysfunction.

We observed that out of the 111 pregnancies associating thyroid pathology, in 24 cases the pregnancy was not monitored by any kind of health care provider. This is a major factor in a developing country, and a continuous source of monetary loss for our health care system.

As far as the ultrasound characteristics go, ultrasound examination of the thyroid gland does not require prior patient preparation; it should be preceded by a clinical consultation of the neck region, evaluating symmetry, dimensions of the gland as well as the

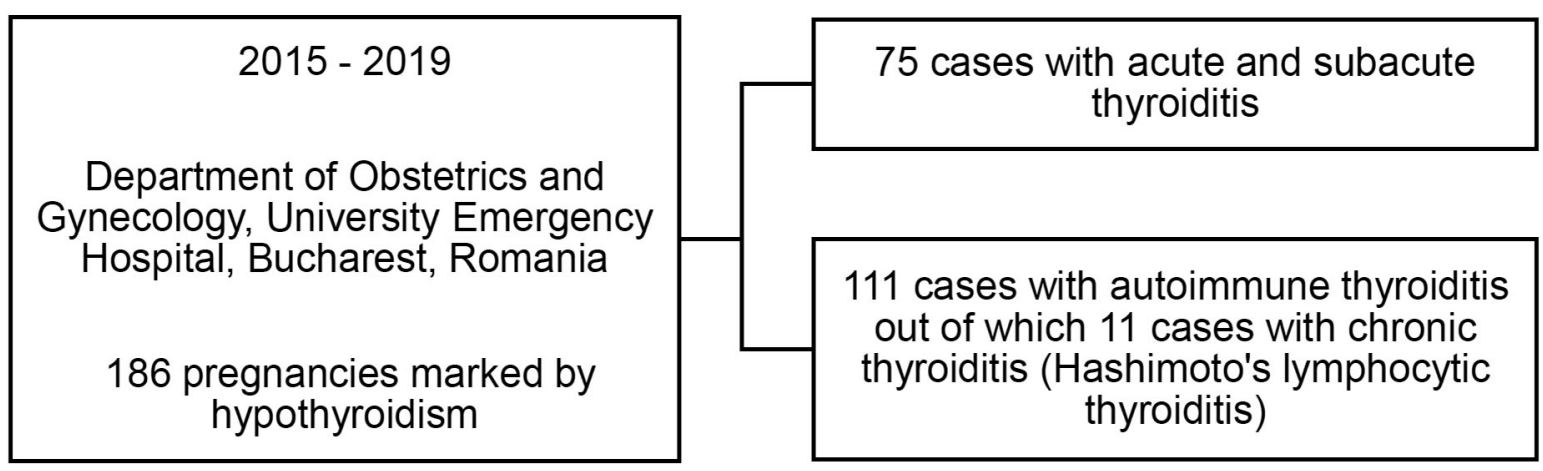

Figure 1. Distribution of pregnant women with hypothyroid pathology treated during 55 months in the Department of Obstetrics and Gynecology of Bucharest Emergency University Hospital 
presence of cervical adenopathy. The use of ultrasound examination of the thyroid gland refers to the most accurate measurement of the thyroid volume, hence providing the early diagnosis of diffuse pathologies and the detection and characterization of nodular lesions. Determining the volume of the thyroid is one of the most common purposes for which thyroid ultrasound is performed - hypertrophy of the thyroid gland being the most common thyroid pathology in our geographical area ${ }^{3}$.

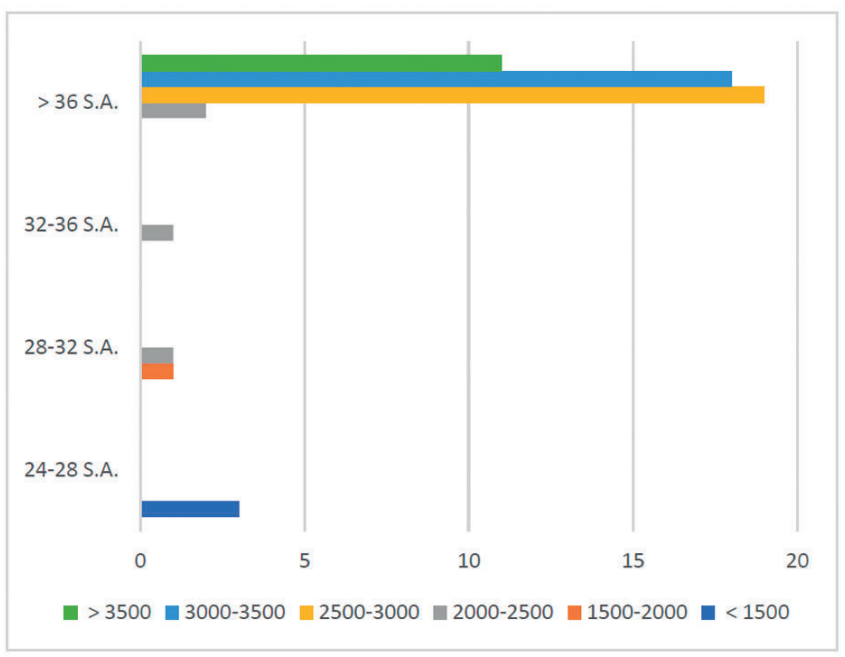

Figure 2. Distribution of fetal gestational age and weight at birth from mothers suffering of autoimmune thyroid pathology during 55 months in the Department of Obstetrics and Gynecology of Bucharest Emergency University Hospital

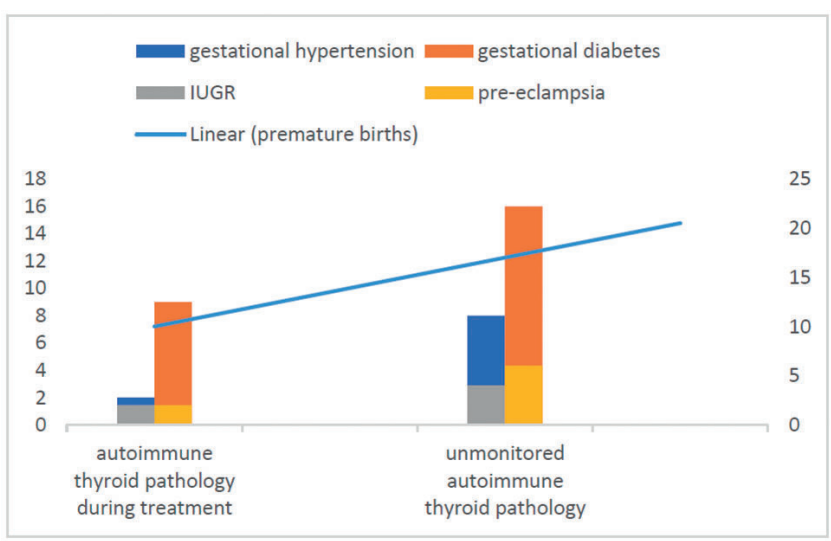

Figure 2. Distribution of pregnant women diagnosed with complications during pregnancies associating autoimmune thyroid pathology, with treatment and unmonitored, during 55 months in the Department of Obstetrics and Gynecology of Bucharest Emergency University Hospital
Regarding the diagnosis of diffuse thyroid diseases, the thyroiditis is on the first place. In acute and subacute thyroiditis, the clinical picture is suggestive of the diagnosis, the importance of ultrasound being in monitoring the evolution of the disease under treatment.

In acute thyroiditis, the ultrasound of the gland highlights hypertrophy with multiple hypoechoic areas, imprecisely delimited, which may evolve under treatment to remission or may form abscesses needing surgical drainage in order to avoid spontaneous fistulation to mediastinum.

In subacute thyroiditis the ultrasound aspect is homogeneous, hypoechoic hypertrophy. Under treatment - corticosteroid - it can evolve with healing - return to the isoechoic aspect, or persistence of hypoechoic areas that show the continuation of the inflammatory process.

In chronic thyroiditis (Hashimoto's lymphocytic thyroiditis) the contribution of the ultrasound is major, especially due to the very poor clinical picture. The ultrasound aspect is suggestive: diffuse hypertrophy of the gland, polycyclic contour, micronodular structure (nodules between $1 \mathrm{~mm}$ and $5 \mathrm{~mm}$ in diameter - „painted” appearance) and hypoechoic. Also, there is evidence of calcifications and increased vascularization, a pseudo lobulated aspect through the development of fibrous septa. Confirmation of the diagnosis is made by determining TPOAb and thyroid hormones, Hashimoto's thyroiditis being an autoimmune disease.

Levothyroxine (LT4) is the treatment of choice for hypothyroidism in both pregnant woman as well as other categories of patients. The therapeutic target during substitution treatment is to keep TSH values below $2.5 \mathrm{mIU} / \mathrm{mL}^{5}$. If the treatment is started during pregnancy, it is best to start with the closest dose to the estimated final dose, in order to reduce the time of exposure to thyroid hormone deficiency to the maximum. In patients previously known to have hypothyroidism due to the increased levels of protein-carrier during pregnancy, the necessary for LT4 increases. To reduce the risk of hypothyroidism during pregnancy, these women must have optimal TSH levels prior to conception $<2.5 \mathrm{mIU} / \mathrm{ml}^{6}$. Because even in these cases TSH values may increase inappropriately in the first trimester in about $27 \%$ of women, some authors recommend that the value of TSH before conception to be $<1.5 \mathrm{mIU} / \mathrm{ml}$. fT 4 can also be used as a therapeutic target: it's plasma concentration must be located in the upper third of the normal range ${ }^{7}$. The etiology of hypothyroidism influences the dose of thyroid hormone 
substitution in pregnancy. Women with postoperative hypothyroidism or post-radiotherapy receive higher doses than those with primary hypothyroidism, regardless of preconception levels of $\mathrm{TSH}^{8}$.

Because only $60-80 \%$ of the ingested LT4 is absorbed in the intestine and that food and food supplements further reduce this percentage, patient training is essential in the correct administration of the medication. It is necessary to allow a period of 30-60 minutes between the administration of the substitution dose and the ingestion of food or caffeine. Also, prenatal calcium and iron supplements should be taken after an interval of $4-6$ hours. If the hypothyroidism persists when administering high doses of LT4, one is required to assess the compliance treatment and the coexistence of gastroenterological diseases that give malabsorption (celiac disease, gastritis, atrophies etc.) ${ }^{9-11}$.

\section{CONCLUSIONS}

Pregnancy can be considered a stress test for the thyroid, leading to hypothyroidism in cases with limited functional reserves. Universal screening for thyroid dysfunction and euthyroid autoimmune disease during pregnancy remains controversial. Observational studies have shown both maternal and fetal adverse outcomes in women with subclinical hypothyroidism and in euthyroid women with thyroid autoantibodies. Up until now, there is limited evidence to highlight the benefits of LT4 treatment on the pregnancy outcome. TSH screening should be performed during pregnancy and all pregnant patients with subclinical hypothyroidism should receive treatment. However, we cannot recommend universal screening at this time, given the lack of interventional studies. As more data on the effectiveness of treatment and screening for thyroid dysfunction in pregnant women become available, recommendations for thyroid testing during pregnancy and clinical practice patterns are likely to become more uniform.

Compliance with ethics requirements: The authors declare no conflict of interest regarding this article. The authors declare that all the procedures and experiments of this study respect the ethical standards in the Helsinki Declaration of 1975, as revised in 2008(5) and the national law. Informed consent was obtained from the patient described in the clinical case and his parents.

\section{References}

1. Korevaar TIM, Medici M, Visser TJ, Peeters RP. Thyroid disease in pregnancy: new insights in diagnosis and clinical management. Nat Rev Endocrinol. 2017; 13:610-22

2. Stagnaro-Green A, Dong A, Stephenson MD. Universal screening for thyroid disease during pregnancy should be performed. Best Pract Res Clin Endocrinol Metab. 2020 Jul;34(4):101320. doi: 10.1016/j. beem.2019.101320. Epub 2019 Sep 6.

3. Stagnaro-Green A, Pearce E. Thyroid disorders in pregnancy. Nat Rev Endocrinol. 2012; 8:650-8.

4. Sahay RK, Sri NV. Hypothyroidism in pregnancy. Indian J Endocrinol Metab. 2012; 16:364-70.

5. Loh JA, Wartofsky L, Jonklaas J, Burman KD. The magnitude of increased levothyroxine requirements in hypothyroid pregnant women depends upon the etiology of the hypothyroidism. Thyroid. 2009; 19:269-75

6. Kothari A, Girling J. Hypothyroidism in pregnancy: pre-pregnancy thyroid status influences gestational thyroxine requirements. BJOG. 2008; 115:1704-8.

7. Kashi Z, Bahar A, Akha O, Hassanzade S, Esmaeilisaraji L, Hamzehgardeshi Z. Levothyroxine dosage requirement during pregnancy in well-controlled hypothyroid women: a longitudinal study. Glob J Health Sci. 2015; 8:227-33.

8. Alexander EK et al. Timing and magnitude of increases in levothyroxine requirements during pregnancy in women with hypothyroidism. N Engl J Med. 2004; 351:241-9.

9. Busnelli A, Vannucchi G, Paffoni A, et al. Levothyroxine dose adjustment in hypothyroid women achieving pregnancy through IVF. Eur J Endocrinol. 2015; 173:417-24.

10. Poppe K, Velkeniers B, Glinoer D. The role of thyroid autoimmunity in fertility and pregnancy. Nat Clin Pract Endocrinol Metab. 2008; 4:394-405

11. Alexander EK, Pearce EN, Brent GA, et al. 2017 Guidelines of the American Thyroid Association for the diagnosis and management of thyroid disease during pregnancy and the postpartum. Thyroid. 2017; 27:315-89. 